\title{
Malmquist Data Envelopment Analysis as a tool to evaluate the productivity levels of container ports in developing countries located in east and southern Africa
}

\author{
Adeola OSUNDIRAN, Felix OKONTA \\ University of Johannesburg, South Africa
}

\begin{abstract}
:
Aim: The purpose of this paper is to examine the productivity of 12 container ports located in East and Southern African developing nations for the period of 2014-2016. Furthermore, to investigate the sources of productivity change over the time period.
\end{abstract}

Design / Research methods: This research collects data on the 12 container ports. The productivity of these ports is analyzed using the Data Envelopment Analysis based Malmquist productivity index. This is decomposed into technological changes and technical efficiency. The sources of productivity change are identified.

Conclusions /findings: The major finding of this study is the trend in the port efficiency level over the three year period of analysis. Therefore assisting maritime policymakers and port authorities on what aspect of the port production need enhancement.

Originality/value of the article: Evaluation of ports in developing nations in Africa is not common. Also, the year under examination is less than five years. Therefore the result is relevant to port authorities as well as to the African nations.

Implications of the research: $90 \%$ of import and exports into developing African nations are done by sea. The implication of this is that an efficient or inefficient port will have a multiplier effect on the nation's economy. Great improvement in port productivity will enhance economic growth and development.

Limitations of the research: Port efficiency should be evaluated on a yearly basis to serve as a major determinant of port productivity. However, this evaluation is based on availability of data.

Key words: Ports, Data Envelopment Analysis, African Nations, Developing, Malmquist.

JEL: C33, L9

Correspondence address: Adeola OSUNDIRAN, Felix OKONTA,. E-mail: 216088926@student.uj.ac.za, fnokonta@uj.ac.za

Received: 02.10.2017, Revised: 08.02.2018, Revised: 01.03.2018, Accepted: 17.03.2018

doi: http://dx.doi.org/10.29015/cerem.573 


\section{Introduction}

The term port comes from the Latin portus, which means gate or gateway (Rodrigue, Notteboom 2017). A seaport is an area of land and water with related equipment to permit the reception of ships, their loading, and unloading and the receipt storage and delivery of their goods (Coyle et al. 2011: 115). Port terminals play an integral role in the logistics chain by providing cargo-handling services to a wide spectrum of customers, including shipping lines, freight forwarders and various types of organizations. This paper focuses on the port productivity over 2014, 2015 and 2016 for the following ports located in the selected developing nations. The ports include; the Port of Mombasa in Kenya, the Ports of Richards Bay, Durban, East London, Coega, Port Elizabeth and Cape Town in South Africa, the Port of Nacala in Mozambique, the Port of Dar es Salaam in Tanzania, the Doraleh Container Terminal and Djibouti Port in Djibouti and the Port of Port Louis in Mauritius. These ports represent countries in the Southern and Eastern Part of Africa.

Measuring efficiency and productivity is an integral part of any productivity improvement goal (Cabanda, Emrouznejad 2014). The purpose of this paper is to evaluate the performance of selected Africa Ports based on its productivity and efficiency over a period of time. The focus is on the performance of container ports which converts inputs into outputs. Service organizations use and apply benchmarking techniques for measurement of service efficiency (Cabanda, Emrouznejad 2014). The Data Envelopment Analysis model is based on a linear programming technique that evaluates the efficiency of entities relative to best practice observations (Charnes et al. 1978). Fare, Grosskopf, Lindgren and Roos (1994) used DEA to compute a Malmquist Production Index (MPI) which measures a unit's overall productivity change. The DEA based Malmquist Production index captures productivity change in terms of quantities without reference to input prices or output values.

Since 1978 little research has made use of Malmquist Production Index to evaluate ports in Southern and Eastern Africa. A decomposition of calculated Malmquist indices make it possible to identify what factors whether technical 
efficiency or technological progress determines the changes in seaports productivity in 2014-2016. This paper, therefore, makes use of DEA based MPI to evaluate the performance of 12 selected Southern and Eastern Africa ports over a three year period. Port evaluation is critical for these regions because of the famine, drought and other natural disasters that have affected the horn of Africa. The ports located in East Africa have a pivotal role to play in the distribution of humanitarian relief shipment. Therefore, the efficiency of these ports are critical. This paper is categorized into six segments. Section 2 will focus on concepts and objectives; section 3 focuses on the variables, data and method, Section 4 deals with the results and discussion, whilst Section 5 focuses on the conclusion and recommendation.

\section{Concepts and objectives}

For the purpose of evaluation, the decision-making units are ports. This section focuses on the definition of terms and concepts.

Container ports serve as an important node in facilitating the efficient flow of containerized cargoes (Notteboom, Yap 2012). The container port is further differentiated by its functions, which consists of serving primarily as a gateway port that acts as an interface between hinterland and deep-sea routings of containerized cargoes, or of serving primarily as a transhipment port that acts as an interface for interchange between deep-sea routings of containerized cargoes (Notteboom, Yap 2012).

A container terminal can be defined as any location where freight and passengers either originates, terminates or are handled in the transportation process (Rodrigue, Slack 2017). Terminals require specific facilities and equipment to accommodate the traffic that they handle (Rodrigue, Slack 2017). Terminal operators want to maximize operational productivity and land space as containers are handled at the berth and in marshaling yards. Container handling productivity is directly related to the transfer functions of a container terminal, including the number and movement rate of quayside container cranes, the use of yard equipment 
and the productivity of workers employed in waterside, landside and gate operations (Le-Griffin, Murphy 2006).

\subsection{Brief background of the ports}

This section gives a brief overview of the ports that are being evaluated in both the East and Southern Africa. Ports in the East Africa sub-region, includes the Port of Mombasa, Port of Djibouti, Doraleh Container Terminal, and the Port of Dar es Salaam. In the Southern Africa sub-region, the ports covered includes the Ports of Richards Bay, Durban, East London, Ngqura, Cape Town, and Nacala. The Port of Port Louis is an Indian Ocean island nation.

\section{Port of Mombasa}

The Port of Mombasa is a critical gateway for Central Africa's landlocked countries. Developments in the port are, therefore, of great significance (Foster, Briceno-Garmendia 2010). The Port of Mombasa is the busiest port in East Africa. It serves countries such as Uganda, Rwanda, Burundi, South Sudan and the eastern gateway of the Democratic Republic of Congo (DRC) (African Development Bank 2010: 60). The port handles containers, general cargo, dry bulk and liquid bulk.

\section{Port of Djibouti and Doraleh Container Terminal}

These two ports are located in Djibouti. Djibouti is positioned at the Horn of Africa. Its strategic location makes it efficiency key to Ethiopia. According to African Development Bank (2010: 60), the Djibouti terminal offers the most modern facilities but needs more investment to meet the high transit demand from Ethiopia. For decades, Ethiopia as a developing nation has suffered from famine.

\section{Port of Dar es Salaam}

The Port of Dar es Salaam is located in Tanzania. This port's efficiency is critical to other countries such as Zambia, Malawi, DRC, Burundi and Rwanda that makes use of its services. 


\section{Ports in South Africa}

Transnet Port Terminals oversee the Ports of Richards Bay, Durban, East London, Ngqura, and Cape Town in South Africa. These ports handle most of Southern African imports and exports. Furthermore, these ports play an important role for the landlocked economies of the sub-region including Botswana, Lesotho, Swaziland, Malawi, Zimbabwe and Zambia (African Development Bank 2010: 65).

\section{Port of Nacala}

The Port of Nacala is located in Mozambique. Though Mozambique has other ports such as the Port of Maputo and Beira, the focus is on the Port of Nacala. The Port of Nacala has a rail connection to Malawi (African Development Bank 2010: 62). Malawi is land logged.

\subsection{Container port production process}

The ports are categorized as decision making units and homogenous because of the similarity involved in the production processes. In maritime transportation, port throughput is the total number of tons loaded and unloaded within a certain period. In statistical records or handbooks, this data consists of both imports and exports. Throughput is, therefore, the sum of import and export cargoes (Tetteh et al. 2016). At the container Ports, four major operations take place. See Figure 1.

\section{Figure 1. Container production process}

Quay Transfer operations

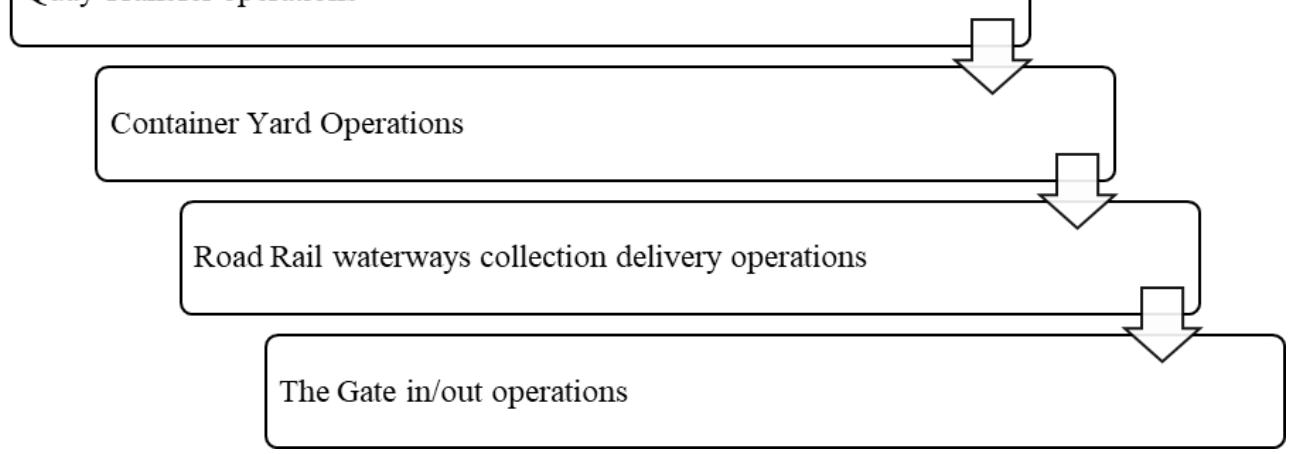

Source: authors' own elaboration. 


\section{Adeola OSUNDIRAN, Felix OKONTA}

- Quay transfer operations

The container vessel arrives at the Port. At the port, the container is loaded/unloaded from the ship with the use of a ship-to-shore crane and placed in the port's apron, the staging location. These are operations that refer to the transfer of containers from the quayside to the stacking areas or vice versa.

- Container yard operations

These are operations that involve the positioning of the container into a container stacking yard before being loaded onto the vessel as export, or before being moved out of port as imports or being loaded onto another vessel as transshipment.

- Road-rail-waterways collection delivery operations

These are all the necessary actions that allow the container to be loaded or unloaded onto a truck (road transport) or train or water barge. Container ports that have on-site rail services also have rail entry and departure gates for trains transporting containers to and from the port.

- The gate in/out operations

This mostly relates to road transport. It refers to all the documentation necessary for the container to be loaded onto a vessel for export, or loaded onto a truck as an import. The inland interchange gate allows for the entry and departure of containers by land (or inland waterways) to and from the ports. Imported or exported containers are subject to inspection for proper documentation and security requirements. These gates consist of entry and departure gates. For instance, a truck may arrive at the entry gate with a chassis loaded with a container. At the truck entry gate, relevant information regarding truck movements is recorded. For example, information on the containers being hauled, the ships on which the containers will be loaded and the trucks and their chassis hauling the containers.

\subsection{Seaport performance}

There are two main research lines on the performance of seaports. These are the productivity evaluation and the efficiency evaluation (Baran, Gorecka 2015). Please see Figure 2. 


\section{Figure 2. Sea port performance theory}

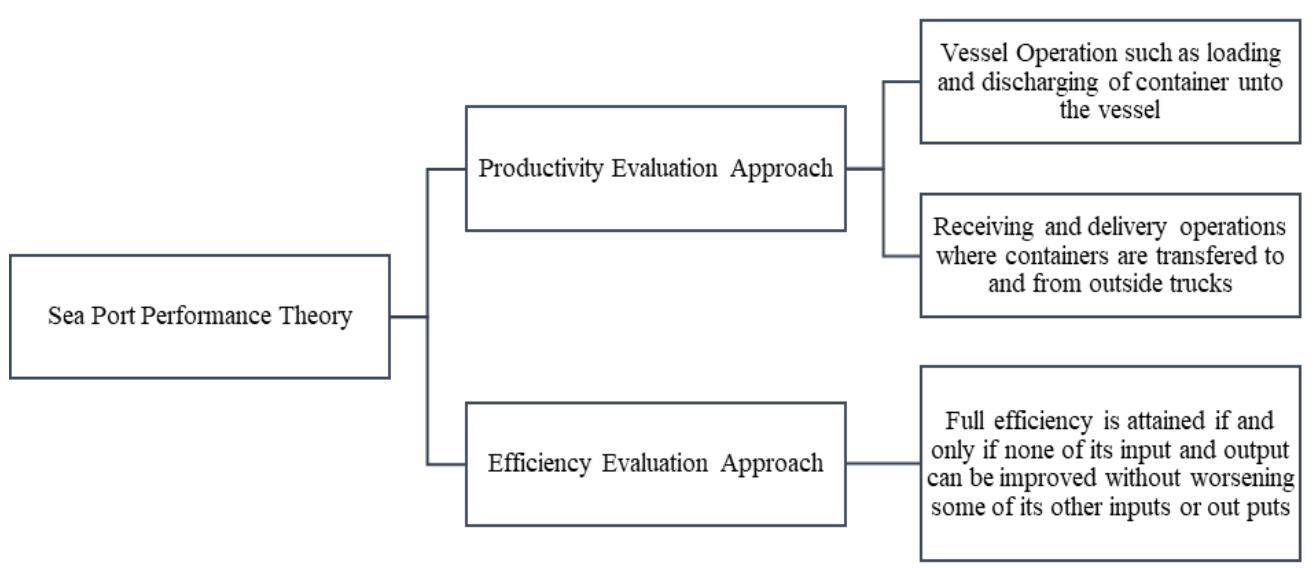

Source: authors' elaboration based on Baran, Gorecka (2015)

\subsubsection{Technical efficiency}

The first component of economic efficiency is technical, or productive, efficiency, which has been defined in several different manners in the literature. To Koopmans (1951: 33) a producer is technically efficient if an increase in any output or a decrease in any input requires a decrease in at least one other output or an increase in at least one input. Thus, for each technology for which isoquant and efficient subset diverge, there is a potential conflict between both technical efficiency concepts (Infante et al. 2013). In DEA, this is the output-oriented analysis.

\subsubsection{Allocative efficiency}

Allocative efficiency is achieved when resources are not wasted (Infante et al. 2013). Allocative efficiency in input selection involves selecting that mix of inputs (e.g labor and capital) that produces a given quantity at minimum cost. (Coelli et al. 
2005).There are three conditions to be met for efficient allocation. This is economic efficiency, which involves technological efficiency as well as the use of production factors in such proportions in which costs are minimized (Infante et al. 2013). Consumer efficiency when consumers fail to improve after reassigning their budgets. Thirdly where the cost of producing additional product units equal to the benefits. The MC=MSB, where MC is marginal cost and MSB is a marginal social benefit. (Infante et al. 2013). Allocative and Technical efficiency combine to provide an overall economic efficiency measure (Coelli et al. 2005)

\subsection{Review of literature on Data Envelopment Analysis based Malmquist Production Index}

The researcher consulted several peer-reviewed journal to have a better understanding of how DEA based MPI has been used to evaluate container ports over the years. Several of the journals focused on Latin American, European and Asian Ports. Only one peer-reviewed article focused on an African nation. Baran \& Gorecka (2015) used the Malmquist DEA to evaluate the seaport efficiency and productivity of the 18th world leading container ports. The paper used the Malmquist productivity to determine and analyze the productivity change and its decomposition of four container terminals during 1996-2012. Diaz-Hernandez (2008), used Malmquist DEA to measure productivity changes in cargo handling operations in Spanish ports for a period of 1994-1998. Bo-xin and Guo (2009) also investigated the long-term operating efficiencies of 10 leading container ports in China from 2001-2006. Nwanosike, Tipi and Warnock-Smith (2016) used the Malmquist productivity index decomposition approach to benchmark pre and postreform total factor productivity growth of six major Nigerian seaports. These are Apapa, Calabar, Onne, Port Harcourt, Tincan Island and Warri Ports for six years before the reform 2000-2005 and six years after the reform 2006-2011. NúñezSánchez and Coto-Millán (2012) analyzed the evolution of total factor productivity and its decomposition between 1986 and 2005 in the Spanish ports. Estache, Tovar and Trujillio (2004) use the MPI to measure the changes in, and sources of efficiency since the Mexican reform. 11 main Mexican ports were evaluated from 1996-1999. Cheon, Dowall and Song (2010) evaluated how port institutional 
reforms influenced efficiency gains between 1991 and 2004. 98 major world ports were used and the MPI model was used.

\section{Variables, data and method}

This section examines the variables, data and methodology used for this research.

\subsection{Variables}

The variables used for this research includes the countries earmarked in the African map shown in Figure 3. The map captures six African nations where the 12 container ports are located in: the Port of Mombasa in Kenya, the Port of Richards Bay, the Port of Durban, Port of East London, the Port of Coega, Port of Port Elizabeth, the Port of Cape Town in South Africa, the Port of Nacala in Mozambique, the Port of Dar es Salaam in Tanzania, the Port of Djibouti and the Doraleh Container Terminal in Djibouti and the Port of Port Louis in Mauritius.

For the purpose of analysis, four inputs were used and one output. See Table 1 that shows the inputs and outputs used for this analysis. The inputs and outputs are of immense significance to the container ports. The number of container berths determines the volume of containers that the container port can handle. The cargo handling equipment such as cranes determines and enhances container offloading and on loading in the vessels. The number of cranes at a container terminal has a direct effect on how fast or slow a particular ship is worked on at the terminal because when there are more cranes at the terminal, it increases the number of containers handled per-ship-hour. When there are more ship cranes at a port, the terminal is able to handle more ships at the same time and this increases the scalability of the port (Tetteh et al. 2016). Tugs are critical to guide the movement of the containerships when the ply the unchartered African seashores. The length of the quay determines the ability of the vessel to turn around. The output of a container terminal is seen in the number of TEUs it is able to clear, transshipped or handled. The number of TEUs that a terminal handles determine its productivity (Turner et al. 2003). 
Figure 3. Selected east and southern African nations

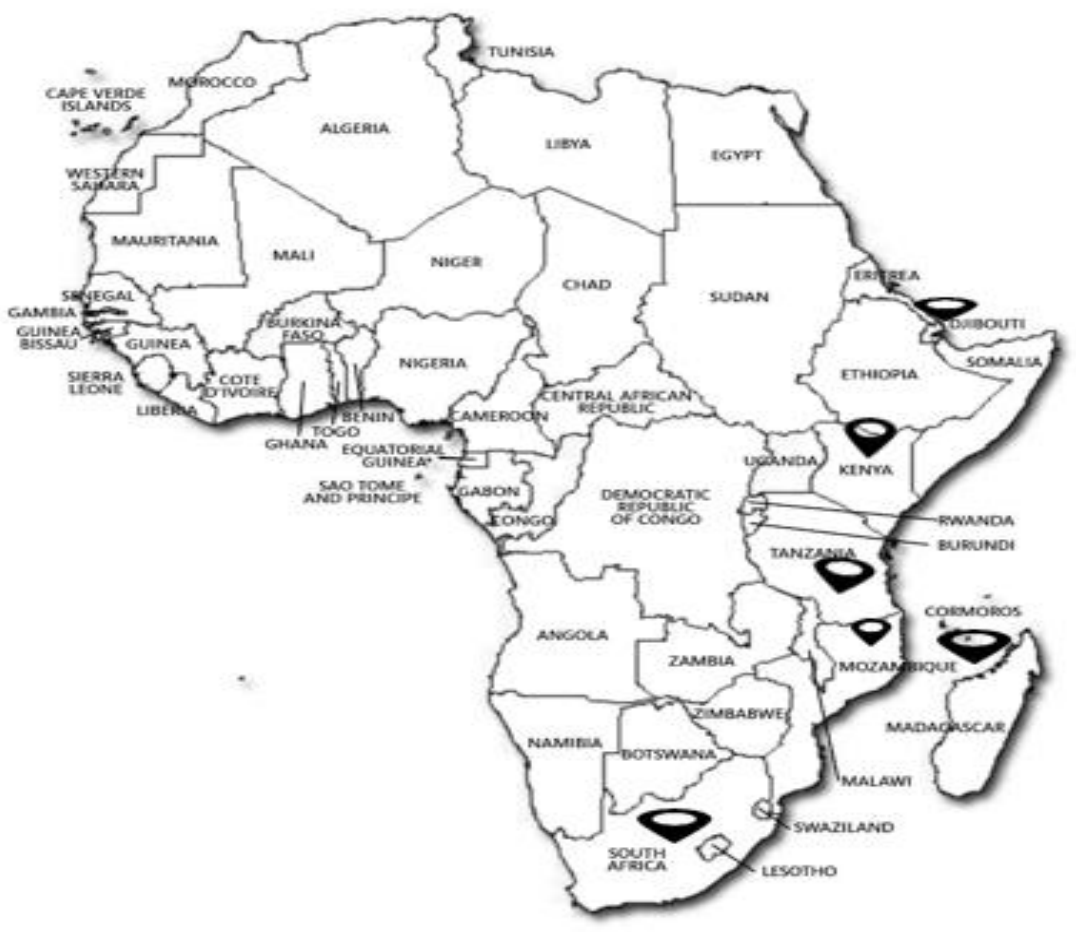

Source: authors' fieldwork, 2017.

\section{Table 1. Input and output table}

\begin{tabular}{|l|l|}
\hline Inputs & Outputs \\
\hline Number of Container Berths & Container Throughput \\
\hline Number of Cranes & \\
\hline Number of Tugs & \\
\hline Length of Quay & \\
\hline
\end{tabular}

Source: authors' fieldwork, 2017.

\subsection{Data}

Data were obtained and then collated from various ports website. For data not on the website, the researcher approached the ports representatives and regional association representatives via email and they responded with the correct data for the 
period of analysis. This section focuses on the inputs, output used for the MPI analysis. See Table 2.

Table 2. Port features 2014-2016

\begin{tabular}{|c|c|c|c|c|c|c|}
\hline Year & DMU & $\begin{array}{c}\text { Number } \\
\text { of } \\
\text { Berths }\end{array}$ & $\begin{array}{l}\text { Number } \\
\text { of Tugs }\end{array}$ & $\begin{array}{c}\text { Number } \\
\text { of } \\
\text { Cranes }\end{array}$ & $\begin{array}{l}\text { Quay } \\
\text { Length }\end{array}$ & $\begin{array}{l}\text { Container } \\
\text { Throughput }\end{array}$ \\
\hline 2014 & Port of Mombasa & 6 & 8 & 4 & 1204 & 1012002 \\
\hline 2014 & Port of Richardsbay & 3 & 0 & 36 & 350 & 24189 \\
\hline 2014 & Port of Durban & 7 & 23 & 58 & 2550 & 2664330 \\
\hline 2014 & Port of East London & 3 & 0 & 4 & 300 & 41957 \\
\hline 2014 & Port of Coega & 2 & 6 & 23 & 700 & 705377 \\
\hline 2014 & Port of Port Elizabeth & 2 & 0 & 15 & 600 & 259917 \\
\hline 2014 & Port of Cape Town & 4 & 8 & 227 & 1151 & 892557 \\
\hline 2014 & Port of Nacala & 2 & 0 & 2 & 372 & 97081 \\
\hline 2014 & Port of Dar es Salaam & 4 & 5 & 4 & 720 & 414059 \\
\hline 2014 & $\begin{array}{l}\text { Doraleh Container } \\
\text { Terminal }\end{array}$ & 2 & 32 & 5 & 1050 & 793317 \\
\hline 2014 & Djibouti Port & 2 & 4 & 2 & 400 & 70710 \\
\hline 2014 & Port Louis & 2 & 5 & 1 & 560 & 403001 \\
\hline 2015 & Port of Mombasa & 6 & 8 & 4 & 1204 & 1076118 \\
\hline 2015 & Port of Richardsbay & 3 & 0 & 18 & 350 & 19011 \\
\hline 2015 & Port of Durban & 7 & 23 & 60 & 2550 & 2770335 \\
\hline 2015 & Port of East London & 3 & 0 & 1 & 300 & 66293 \\
\hline 2015 & Port of Coega & 4 & 10 & 14 & 700 & 636663 \\
\hline 2015 & Port of Port Elizabeth & 2 & 0 & 10 & 600 & 216629 \\
\hline 2015 & Port of Cape Town & 4 & 8 & 150 & 1151 & 888976 \\
\hline 2015 & Port of Nacala & 2 & 0 & 2 & 372 & 79417 \\
\hline 2015 & Port of Dar es Salaam & 4 & 5 & 4 & 720 & 644619 \\
\hline 2015 & $\begin{array}{l}\text { Doraleh Container } \\
\text { Terminal }\end{array}$ & 2 & 32 & 5 & 1050 & 836800 \\
\hline 2015 & Djibouti Port & 2 & 4 & 2 & 400 & 73365 \\
\hline 2015 & Port Louis & 2 & 5 & 1 & 560 & 361109 \\
\hline
\end{tabular}


Adeola OSUNDIRAN, Felix OKONTA

Table 2. Cont.

\begin{tabular}{|l|l|r|r|r|r|r|}
\hline Year & DMU & $\begin{array}{c}\text { Number } \\
\text { of } \\
\text { Berths }\end{array}$ & $\begin{array}{c}\text { Number } \\
\text { of Tugs }\end{array}$ & $\begin{array}{c}\text { Number } \\
\text { of } \\
\text { Cranes }\end{array}$ & $\begin{array}{c}\text { Quay } \\
\text { Length }\end{array}$ & $\begin{array}{c}\text { Container } \\
\text { Throughput }\end{array}$ \\
\hline $\mathbf{2 0 1 6}$ & Port of Richardsbay & 3 & 0 & 18 & 350 & 12302 \\
\hline $\mathbf{2 0 1 6}$ & Port of Durban & 7 & 23 & 60 & 2550 & 2620026 \\
\hline $\mathbf{2 0 1 6}$ & Port of East London & 3 & 0 & 1 & 300 & 71901 \\
\hline $\mathbf{2 0 1 6}$ & Port of Coega & 4 & 10 & 14 & 700 & 572021 \\
\hline $\mathbf{2 0 1 6}$ & Port of Port Elizabeth & 2 & 0 & 10 & 600 & 152455 \\
\hline $\mathbf{2 0 1 6}$ & Port of Cape Town & 4 & 8 & 150 & 1151 & 926611 \\
\hline $\mathbf{2 0 1 6}$ & Port of Nacala & 2 & 0 & 2 & 372 & 71142 \\
\hline $\mathbf{2 0 1 6}$ & Port of Dar es Salaam & 4 & 5 & 4 & 720 & 603290 \\
\hline $\mathbf{2 0 1 6}$ & Doraleh Container & 2 & 32 & 5 & 1050 & 914017 \\
\hline $\mathbf{2 0 1 6}$ & Derminal & 2 & 4 & 2 & 400 & 73172 \\
\hline $\mathbf{2 0 1 6}$ & Port Louis & 2 & 5 & 1 & 560 & 388514 \\
\hline
\end{tabular}

Source: fieldwork, 2017.

\subsection{Methods}

The Malmquist total factor productivity index was first introduced by Malmquist (1953). Malmquist production index is considered as a standard approach to measuring the efficiency in the light of time changes (Rahsidi et al. 2014; Huguenin 2012). Malmquist model captures the variations in the port performances in the selected ports over a period of time.

$1 / 2$

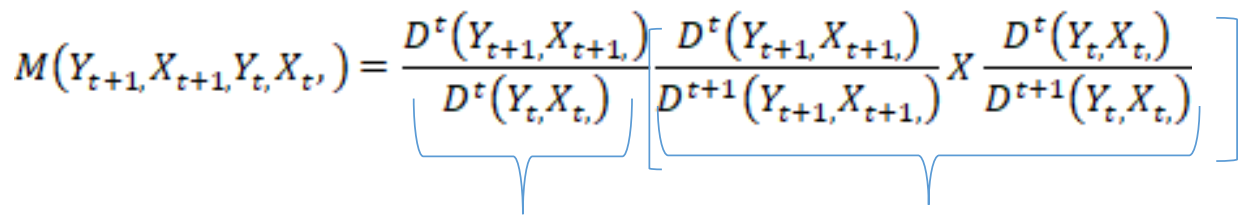

Efficiency change Technological Change

Where:

$X_{\mathrm{t}}$ and $X_{t+1}$ input vectors of dimension at time $t$ and $t+1$

$Y_{t}$ and $Y_{t+1}$ corresponding $k$-output vectors

$D_{t}$ and $D_{t+1}$ denote an input

$D(x, y)=\max (\rho:(\mathrm{x} / \rho \mathrm{x} \in \mathrm{L}(\mathrm{y})$ 
Where $L(y)$ represents the number of all input vectors with which a certain output vector y can be produced, that is $L(y)=(x: y$ can be produced with $x)$.

$P$ in equation (2) can be understood as a reciprocal value of the factor by with the total inputs could be maximally reduced without reducing output.

$M=$ measures the productivity change between periods $t$ and $t+1$. Productivity declines if $M<1$, remains unchanged if $M=1$ and improves if $M>1$.

Computation experiments have been carried out with the application of DEA Malmquist method implemented in the specialized software called PIM-DEA.

\section{Results and discussion}

Malmquist indices measure the productivity change over time at DMU level. The framework describes the interlinking between the inputs and the outputs that were used for evaluation. As the main activity of container ports are handling containers, one output and four inputs were used.

$\checkmark$ Input $X_{1}$-Number of Berths

$\checkmark$ Input $X_{2}$ Number of Tugs

$\checkmark$ Input $X_{3}$ Number of Cranes

$\checkmark \quad$ Input $X_{4}$ Quay Length

$\checkmark$ Output $\mathrm{Y}_{1}$ Container Throughput

\subsection{Technical change}

In the computation of DEA MPI, two major issues are emphasized, firstly it is the technical efficiency change which can also be known as the catch-up effect. The boundary shift technical change, which is also known as the technology change. The efficiency catch up captures the change in technical efficiency between 2014 and 2015; 2015 and 2016. Table 3 and Table 4 shows the technical efficiency and technology change between 2014-2015; 2015-2016.

Table 3 indicates that the Ports of Mombasa, Durban, East London, Port Elizabeth, Nacala, Doraleh Container terminal and Port Louis show Technical Efficiency-TE=1. This implies that there has been not much change in the technical efficiency level of these ports over the three year period. Other ports such as 
Richards Bay, Coega, Cape Town, Dar es Salaam and Djibouti all show TE $<1$. The implication for these ports is that there is need for improvement in their technical efficiency levels. Overall, all the 12 ports need to improve on its technical efficiency levels.

Table 3. Technical efficiency

\begin{tabular}{|l|l|l|}
\hline & Technical Efficiency & \\
\hline DMU & $2014-2015$ & $2015-2016$ \\
\hline Port of Mombasa & 1 & 1 \\
\hline Port of Richardsbay & 0.1504 & 0.1383 \\
\hline Port of Durban & 1 & 1 \\
\hline Port of East London & 1 & 1 \\
\hline Port of Coega & 0.8639 & 0.812 \\
\hline Port of Port Elizabeth & 1 & 1 \\
\hline Port of Cape Town & 0.8395 & 0.9215 \\
\hline Port of Nacala & 1 & 1 \\
\hline Port of Dar es Salaam & 0.9784 & 0.9109 \\
\hline Doraleh Container Terminal & 1 & 1 \\
\hline Djibouti Port & 0.2016 & 0.1996 \\
\hline Port Louis & 1 & 1 \\
\hline Source: authors calculions, & & \\
\hline
\end{tabular}

Source: authors' calculations, 2017.

\subsection{Technological change}

Table 4 shows that the Port of Mombasa maintained a Technological change $\mathrm{TC}=1$ for the years examined. The Port of Mombasa needs to improve on its technology change. The Port of Richards bay has a TC $<1$ which indicates a need to improve its technological level. There is an increase of 58\% for the port of East London, however, there is still need for much improvement in terms of technology. The port of Coega shows a slight decline in technology. The Ports of Port Elizabeth, Nacala, Doraleh Container Terminal and Port Louis had a $\mathrm{TC}=1$. This means that there is no progressive shift in technology. Other ports like the Ports of Cape Town, Dar es Salaam and Djibouti had TC level of less than 1, which implies a decline in technology. 
MALMQUist DATA ENVELOPMENT ANALYSis AS A toOL TO EVALUATE THE ...

Table 4. Technological change

\begin{tabular}{|l|l|l|}
\hline & Technology Change & \\
\hline DMU & $2014-2015$ & $2015-2016$ \\
\hline Port of Mombasa & 1 & 1 \\
\hline Port of Richardsbay & 0.1595 & 0.1504 \\
\hline Port of Durban & 1 & 1 \\
\hline Port of East London & 0.4228 & 1 \\
\hline Port of Coega & 0.9933 & 0.8639 \\
\hline Port of Port Elizabeth & 1 & 1 \\
\hline Port of Cape Town & 0.8573 & 0.8395 \\
\hline Port of Nacala & 1 & 1 \\
\hline Port of Dar es Salaam & 0.6656 & 0.9784 \\
\hline Doraleh Container Terminal & 1 & 1 \\
\hline Djibouti Port & 0.206 & 0.2016 \\
\hline Port Louis & 1 & 1 \\
\hline Source: auts & & \\
\hline
\end{tabular}

Source: authors' own elaboration.

\subsection{MPI change}

The MPI is the combination of the Technical efficiency change and the Technological change. For the year 2014 and 2015, the Ports of Mombasa, Durban, Port Elizabeth, Nacala, Doraleh Container Terminal and Port Louis all maintained a MPI=1. An indication of no improvement. Other ports such as Ports of Richards Bay, East London, Coega, Cape Town, Dar es Salaam and Djibouti had MPI <1 which shows that there is room for improvement. Please see Table 5.

For the year 2015-2016, please see Table 6, the Ports of Mombasa, Durban, East London, Port Elizabeth, Nacala, Doraleh Container Terminal and Port Louis maintained MPI=1. This means no improvement. Other ports such as Port of Richards Bay, Coega, Cape Town and Dar es Salaam and Djibouti had MPI $<1$. This implies the need for improvement. 
Adeola OSUNDIRAN, Felix OKONTA

Table 5. MPI 2014-2015

\begin{tabular}{|l|l|l|l|}
\hline & Technical Efficiency & Technology Change & MPI \\
\hline Port of Mombasa & 1 & 1 & 1 \\
\hline Port of Richardsbay & 0.1504 & 0.1595 & 0.023989 \\
\hline Port of Durban & 1 & 1 & 1 \\
\hline Port of East London & 1 & 0.4228 & 0.4228 \\
\hline Port of Coega & 0.8639 & 0.9933 & 0.858112 \\
\hline Port of Port Elizabeth & 1 & 1 & 1 \\
\hline Port of Cape Town & 0.8395 & 0.8573 & 0.719703 \\
\hline Port of Nacala & 1 & 1 & 1 \\
\hline Port of Dar es Salaam & 0.9784 & 0.6656 & 0.651223 \\
\hline Doraleh Container Terminal & 1 & 1 & 1 \\
\hline Djibouti Port & 0.2016 & 0.206 & 0.04153 \\
\hline Port Louis & 1 & 1 & 1 \\
\hline Source aurs & & & \\
\hline
\end{tabular}

Source: authors' calculation, 2018.

Table 6. MPI 2015-2016

\begin{tabular}{|l|l|l|l|}
\hline & Technical Efficiency & Technology change & \multicolumn{1}{|c|}{ MPI } \\
\hline Port of Mombasa & 1 & 1 & 1 \\
\hline Port of Richardsbay & 0.1383 & 0.1504 & 0.0208 \\
\hline Port of Durban & 1 & 1 & 1 \\
\hline Port of East London & 1 & 1 & 1 \\
\hline Port of Coega & 0.812 & 0.8639 & 0.701487 \\
\hline Port of Port Elizabeth & 1 & 1 & 1 \\
\hline Port of Cape Town & 0.9215 & 0.8395 & 0.773599 \\
\hline Port of Nacala & 1 & 1 & 1 \\
\hline Port of Dar es Salaam & 0.9109 & 0.9784 & 0.891225 \\
\hline Doraleh Container Terminal & 1 & 1 & 1 \\
\hline Djibouti Port & 0.1996 & 0.2016 & 0.040239 \\
\hline Port Louis & 1 & 1 & 1 \\
\hline Sounce aur & & & \\
\hline
\end{tabular}

Source: authors' calculation, 2018. 


\section{Conclusion and recommendation}

The purpose of this paper is to evaluate the efficiency of the 12 African container ports. The panel data is over the period of 2014-2016. The productivity change was decomposed in to efficiency change and technological change. This was based on the 4 inputs and 1 output used. For the Ports that have $\mathrm{M}<1$ there is productivity decline, while ports that have $M=1$ indicates that there is productivity stagnancy. The changes in port productivity was as a result of the changes in technology and technical efficiency. Overall, six ports between 2014 and 2015 had MPI=1, whilst the number of ports increased to seven between 2015-2016. For ports that shows decline in Malmquist Production index, port authorities should focus on improving the technical efficiency and technological change.

\section{References}

African Development Bank (2010), African Development Report 2010. Port, logistics and trade in Africa, Oxford University Press, New York.

Baran J., Gorecka A. (2015), Seaport efficiency and productivity based on Data Envelopment Analysis and Malmquist Productivity Index, ,Logistics \& Sustainable Transport”, vol. 6 no. 1, pp. 25-33.

Bo-xin F., Xiang-qun S., Zi-jian G. (2009), DEA-based Malmquist Productivity Index measure of operating efficiencies. New insights with an application to container ports, „Journal of Shanghai Jiaotong University (Science)", vol. 14 no. 4, pp. 490-496.

Charnes A., Cooper W.W., Rhodes E. (1978), Measuring the efficiency of decision making units, „European Journal of Operational Research”, vol. 2 no. 6, pp. 429-444.

Cheon S., Dowall D.E., Song D. (2010), Evaluating impacts of institutional reforms on port efficiency changes. Ownership, corporate structure, and total factor productivity changes of world container ports, „Transportation Research. Part E”, vol. 46 no. 4, pp. 546-561.

Coelli T.J., Prasada Rao D.S., O’Donnell C.J., Battese G.E. (2005), An introduction to efficiency and productivity analysis, 2nd ed., Springer, Boston.

Coyle J.J., Novack R.A., Gibson B.J., Bardi E.J. (2011), Transportation. A supply chain perspective, 7th ed., South-Western Cengage Learning, Mason $\mathrm{OH}$.

Diaz-Hernandez J.J., Martinez-Budria E., Jara-Diaz S.R. (2008), Productivity in cargo handling in Spanish ports during a period of regulatory reforms, „Network and Spatial Economics”, vol. 8 no. 2, pp. 287-295. 


\section{Adeola OSUNDIRAN, Felix OKONTA}

Cabanda E., Emrouznejad A. (ed.) (2014), Managing service productivity. Using frontier efficiency methodologies and multicriteria decision making for improving service performance, Springer, New York.

Estache A., Tovar de la Fe B., Trujillo L. (2004), Sources of efficiency gains in port reforms. A DEA decomposition of a Malmquist TFP index for Mexico, „Utilities Policy”, vol. 12 no. 4, pp. 221-230.

Fare R., Grosskopf S., Lindgren B., Roos P. (1994), Productivity developments in Swedish hospitals. A Malmquist output index approach, in: Data Envelopment Analysis. Theory, methodology and applications, Charnes A., Cooper W.W. (ed.), Springer, Dordrecht.

Huguenin J. (2012), . Data Envelopment Analysis (DEA). A pedagogical guide for decision makers in the public sector, Swiss Graduate School of Public Administration, Lausanne.

Infante Jiménez Z., Gutierrez A., Ortiz-Paniagua C.-F. (2013), Port efficiency in APEC, in: Proceedings of APEC Study Centre Consortium Conference 2013, https://www.researchgate.net/publication/262637197_Port_Efficiency_in_APEC [08.09.2018].

Koopman T.C. (1951), An analysis of production as an efficient combinations of activities, John Wiley and Sons Inc, New York.

Le-Griffin H.D., Murphy M. (2006), Container terminal productivity. Experiences at the port of Long Beach and Los Angeles, in: Container terminal productivity. Conference proceedings, http://citeseerx.ist.psu.edu/viewdoc/download?doi=10.1.1.410.615\&rep=rep1\&type=pdf [08.09.2018].

Malmquist S. (1953), Index numbers and indifference surfaces, „Trabjos de Estatistica”, vol. 4 no. 2, pp. 209-242.

Nooteboom T., Yap Y.Y. (2012), Port competition and competitiveness, in: The Blackwell Companion to Maritime Economics, Talley W.K. (ed.), Blackwell, Hoboken.

Nunez-Sanchez R., Coto-Millan P. (2012), The impact of public reforms on the productivity of Spanish ports. A parametric distance function approach, „Transport Policy”, vol. 24C, pp. 99-108.

Nwanosike F.O., Tipi N.S., Warnock-Smith D. (2016), Productivity change in Nigerian seaports after reform. A Malmquist productivity index decomposition approach, „Maritime Policy \& Management”, vol. 43 no. 7 , pp. 798-811.

Rashidi S.F., Barati R., Kamali Z. (2014), Measurement efficiency by Malmquist method in Data Envelopment Analysis, „Trends in Applied Sciences Research”, vol. 9 no. 1, pp. 54-60.

Rodrigue, J.P., Notteboom T. (2017), Port terminals, in: The geography of transport systems, Rodrigue J.P., Slack B. (ed.), 4th ed., Routledge, New York, https://transportgeography.org/?page_id=3235 [08.09.2018].

Rodrigue J.P., Slack B. (ed.) (2017), The geography of transport systems, 4th ed., Routledge, New York, https://transportgeography.org/ [08.09.2018].

Roll Y., Hayuth Y. (1993), Port performance comparison applying Data Envelopment Analysis (DEA), „Maritime Policy and Management”, vol. 20 no. 2, pp. 153-161. 
MALMQuist Data ENVElopment ANALysis AS A toOl to EVALUATE THE ...

Tetteh E.A., Yang H.L., Mama F.G. (2016), Container ports throughput analysis. A comparative evaluation of China and five West African countries seaports efficiencies, „International Journal of Engineering Research in Africa”, vol. 22, pp. 162-173.

Turner H., Windle R., Dresner M. (2003), Northern American container port productivity: 1984-1997, „Transportation Research. Part E”, vol. 40 no. 4, pp. 339-356.

Foster V., Briceno-Garmendia C. (ed.). (2010), Africa's infrastructure. A time for transformation, The World

Bank,

Washington,

https://siteresources.worldbank.org/INTAFRICA/Resources/aicd_overview_english_no-embargo.pdf [08.09.20818]. 